\title{
Studying the Types, Bases and Features of Sale from the Perspective of Islamic Jurists
}

\section{Estudio de los tipos, bases y características de la venta desde la perspectiva de los juristas islámicos}

\author{
Morad Jafarzadeh \\ PhD Student, Department of Jurisprudence and Fundamentals of Islamic Law, \\ Mashhad Branch, Islamic Azad University, Mashhad, Iran \\ https://orcid.org/0000-0002-7775-0534 \\ Seyed Mohsen Razmi \\ Assistant Prof., Department of Jurisprudence and Fundamentals of Islamic Law, \\ Mashhad Branch, Islamic Azad University, Mashhad, Iran \\ https://orcid.org/0000-0002-3853-5348

\section{Mohammad Reza Kazemi Golvardi} \\ Assistant Prof., Department of Jurisprudence and Fundamentals of Islamic Law, \\ Mashhad Branch, Islamic Azad University, Mashhad, Iran \\ https://orcid.org/0000-0003-3343-7164
}

*Correspondence

Email:razmi0109@mshdiau.ac.ir
Cite as:
Jafarzadeh, M., Razmi, SM., \& Kazemi Golvardi, MR. (2021). Studying the Types, Bases and Features of Sale from the Perspective of Islamic Jurists. Propósitos y Representaciones, 9 (SPE3), e1156. Doi: http://dx.doi.org/10.20511/pyr2021.v9nSPE3.1156 


\section{Summary}

Sale is known as one of the most widely used words in Islamic jurisprudence. Islamic jurists have each defined the nature, bases and types of sale as one of the specific and important Islamic contracts. Regarding sale, it should be mentioned that in some definitions, the early Imami jurists considered its nature as the exchange of two properties, while the famous Islamic jurists consider its nature as the demand and acceptance, which makes the object of sale the property of the customer and regards the price as the property of the seller. Another point is that, in the definitions of late and contemporary Imami jurists, there is a kind of semantic alteration in the interpretation of sale. From the view point of Islamic jurists, it seems that the elements of possession and ownership in the sale are concepts with wide conceptual scopes, and this is the superiority and distinction of Imami jurists over other jurists regarding the truth of sale. On the other hand, from the point of view of Islamic jurists, there are different types of sale, the most important of which are strict sale, contractual sale, absent sale, harmful sale, credit sale, general sale, deferred sale, gifted (mohabati) sale, debt sale, Morabahe (a sale based on a fixed price), etc. On the other hand, the bases of sale from the perspective of Islamic jurists are: demand and acceptance, buyer and seller, property sold, and price in the sale contract. Also, the features of sale from the point of view of jurists are: the ownership of the sale, the exchange of the sale, the objectivity of the property, the necessity of the sale contract. The research methodology in this paper is descriptiveanalytical using the library method.

Keywords: sale, Islamic jurists, demand, buyer, seller.

\section{Resumen}

Venta es conocida como una de las palabras más utilizadas en la jurisprudencia islámica. Cada uno de los juristas islámicos ha definido la naturaleza, las bases y los tipos de venta como uno de los contratos islámicos específicos e importantes. En cuanto a la venta, cabe mencionar que en algunas definiciones, los primeros juristas imamis consideraban su naturaleza como el intercambio de dos propiedades, mientras que los famosos juristas islámicos consideran su naturaleza como la demanda y aceptación, lo que hace que el objeto de la venta sea propiedad del cliente y considera el precio como propiedad del vendedor. Otro punto es que, en las definiciones de los juristas Imami tardíos y contemporáneos, hay una especie de alteración semántica en la interpretación de la venta. Desde el punto de vista de los juristas islámicos, parece que los elementos de posesión y propiedad en la venta son conceptos con amplios alcances conceptuales, y esta es la superioridad y distinción de los juristas imamis sobre otros juristas en cuanto a la verdad de la venta. Por otro lado, desde el punto de vista de los juristas islámicos, existen diferentes tipos de venta, siendo las más importantes la venta estricta, la venta contractual, la venta ausente, la venta perjudicial, la venta a crédito, la venta general, la venta diferida, la venta dotada ( mohabati) venta, venta de deuda, Morabahe (una venta basada en un precio fijo), etc. Por otro lado, las bases de la venta desde la perspectiva de los juristas islámicos son: demanda y aceptación, comprador y vendedor, propiedad vendida y precio en el contrato de compraventa. Además, las características de la venta desde el punto de vista de los juristas son: la propiedad de la venta, el intercambio de la venta, la objetividad de la propiedad, la necesidad del contrato de venta. La metodología de investigación en este trabajo es descriptivo-analítica utilizando el método de biblioteca.

Palabras clave: Venta, juristas islámicos, demanda, comprador, vendedor.

\section{Introduction}

Sale refers to a type of transaction in which a commodity is exchanged for a known substitution, whether a good or cash. Sale is among the necessary contracts. In jurisprudential sources, the individual sale is considered as a delay in financial transactions, and according to its long history 
and scope, it is the most expanded topic in the subject of transactions. For that reason, in many cases related to other transactions, the provisions of sale have become a model for extension of the provisions. Sale is the exchange of property for property. The meaning mentioned above is the literal meaning of sale and regarding trade or sale (according to the difference of interpretation in the words chosen by the jurists) the provisions, the types and conditions have been discussed in detail.

The rules of sale in the Holy Quran are generally expressed under common headings and are stated in the narrations in more detail and often in response to the problems raised. The sale and its related issues are one of the most important parts of Imami jurisprudence, and most jurists have discussed it in their books. Regarding the importance and sensitivity of the sale, it is worth mentioning that the Holy Shari'ah (lawgiver) has stated the rules, laws and explained them in different verses of the Qur'an; verses such as (Allah is the best seller), (fulfill the contracts), (trade on mutual consent) are proofs of this claim. In the realm of tradition, there are various narrations from the Imams (peace be upon them) on the importance and expression of the subject of sale, its rules and conditions, and this matter is not hidden from anyone. The conditions, rules, regulations, and sub-rules on the sale are extracted and proved by relying on the sources such as Quran, Sunnah (tradition), consensus and reason, and the verdict of minor cases can be obtained through a series of general and diverse rules and provisions. These general rules are called jurisprudential rules, and the minor rules of sale are subsets of these general rules.

\section{The Concept of Sale}

\section{The concept of sale in literal terms}

The word sale (Bai) means to buy and sell and it is contradictory; therefore, it can be said that the sentence "I sold him this garment" = "I gave it to him and took the price", as it can be said, "I sold him this garment" = "I bought it from him and gave him the price", that the word sale, in the first sentence, means to sell and in the second sentence is used to mean purchase (Luis Maalouf, 1983: 129).

\section{The concept of the term sale from the view point of jurists}

There is a lot of disagreement in Imami jurisprudence regarding the definition of the term sale. Numerous opinions of jurists indicate the existence of a historical upheaval in the definition of sale. Abu al-Salah al-Halabi considered sale to be a contract, the requirement of which is the right to seize the property and submit it (Najafi, 1989, Vol. 22: 204-205). In this definition, the seller and the customer only have the right to seize what is to be sold and the price and they can merely claim the property and the price; however, this definition is not used to determine whether they also become owners, and if the answer is yes, when this ownership will be acquired. Others have considered sale as the transfer of the same property from one person to another in exchange for a valued replacement that is satisfying (Sheikh Tousi, 2008, vol. 2: 76). In this definition, there is no mention of ownership and only the transfer of the property to the customer is pointed out; however, the transfer will be emergent provided that the ownership of the property is transferred. Meanwhile, in this definition, the act of transfer is considered as sale, and for this reason, another jurist has objected to this definition and has considered transfer as the effect and necessity of sale, and has defined sale as the transfer of property from the owner to another person in a special form. In his view, the sale is an act, while the transfer is the effect that act (Mohaghegh Karki, 1408 $\mathrm{AH}$, vol. 4: 55). Another scholar did not suffice with this definition which includes demand, and considered sale as the sum of demand and acceptance that causes transfer (Tabatabaee, $1419 \mathrm{AH}$, vol. 8: 110); and finally, over time, the jurists have realized that the word is merely exaggerated, and that what causes it to be transferred is the affective act of the seller (Khoei, $1422 \mathrm{AH}$, vol. 30: 71), and that the seller uses the words to express this will; and they have considered sale as the mere possession of an object in exchange for a replacement. This definition was first mentioned by Bahr al-Ulum Tabatabaee in the book Masabih, and after him it was accepted by Sheikh Ansari and many jurists.

The deceased Sheikh Ansari defines sale as "exchange of property for property" (Ansari, 1996: 79). And after him, more jurists chose the same definition. Imam Khomeini- may God have mercy 
on him-, examining the various definitions, has stated in his book of sale: "then the fact of selling is exchanging property for property" (Khomeini, 2000: 26). That is, the truth of the sale is the exchange of property for property. In defining sale, the first martyr (shadi Aval) also stated: "the response and acceptance indicate the transfer of the property with known replacements" (second martyr (shadi sani), 1401 AH, vol. 1:221). That is to say, the contract of sale is the demand and acceptance that indicates the transfer of property in exchange for a determined replacement.

\section{Distinguish between seller and customer and between sale and exchange from the point of view of jurists}

The late Hakim says in Minhaj al-Saleheen: "The meaning of close sale means exchange." (Hakim: 20). On the sidelines of this statement, Martyr Sadr said:

This interpretation is correct if the parties disagree, in the sense that one of the two parties has an opinion, especially property, and the other has an opinion on its taxation, but if the man's opinion is the same, the name of the deal is no longer a sale, but an exchange. (Sadr, 1401: 98).

Martyr Sadr has adapted this article from Ayatollah Khoei. He also states that there is a difference between a seller and a customer; Because one of them has property in particular, and the other has its property, but if both views are the same in this regard, it is not a sale and a partnership, but an exchange (Shahroudi: 30-29). But in our opinion, it is not right to assign a sale to a case in which the opinion of the parties is not the same and one has its own opinion and the other has its own opinion. Why, assigning the name of one of the two traded goods to Muthamman and the other to the price or assigning the name of one of the two parties to the transaction to the seller and the other to the customer, is conditional on the parties' disagreement over the property and if both opinions are the same. Each of the two properties is called the price or the price, and each of the two parties is called the seller or the customer. However, assigning the name of sale to a case in which the views of the parties to the property are not the same is not customary Because the sale of goods to goods was common in the beginning of Islam and before, while the views of both parties in the transaction of goods to goods are often the same. In addition, the mere sale is also considered customary, while in most cases the mere sale is the same for both parties to the dinar and the dirham.

The conditions of the substitutes in the contract of sale from the point of view of the jurists Sheikh Ansari believes that the word "sale" appears in the sense that the exchange should be the same and the benefit cannot be exchanged.

The origin of this emergence is twofold:

A) Abstinence: When a person absolutely uses the word sale and says that "ba'at" what comes to mind from this use is the sale of lords and not the sale of benefits and it is very clear that excommunication is a sign of truth.

B) The veracity of the denial: The word sale can be deducted from the possession of the benefit in exchange for the exchange, that is, when it is said:

"I sold you the benefit of the house for ten years." The terms of the sale of benefits, the sale of NIST, so the use of the word "sale" is a benefit of the metaphor of the stone, and the looting of the nature of it is correct. (Sheikh Ansari, 1410, 6: 10).

There is a point of view from what he said as being sold by hand in the eyes of the most powerful, there is a difference of opinion regarding the presence of Naddar, and there is a concern in which she drew a note from Mayan, the sale of notables, who were known as a Kurd, as well as a damn as his rent, with the transfer of well-known benefits. I have used the word "sale" to replace the benefits of Ra Jays, I have learned it, and I believe that it is beneficial from sold sales and compensated reality, and for example, it is true that I use it in Bouyem "I sold you the benefit of studying." (Sheikh Ansari, 1410, Vol. 6: 10). This promise is confirmed by many news items, some of which we will mention:

A) On the authority of Abu Maryam Abi Abdullah (PBUH), he said: A man was asked about his female servant who would break his maid about the plot they gave her if he wanted, or he would marry her, or sell his life service? He said: Yes, he did. (Sheikh Saduq: 72).

Witness in the phrase «Sells his service his life» "He sells his service, his life," meaning the sale of a house, in particular, I served as a managed treasure card (as it was useful to him as a benefactor). 
B) News that indicates the sale and purchase of leased land, including

- On the authority of Muhammad bin Salim, he said: I asked him about the purchase of their land, and he said: There is nothing wrong with buying it so it will be - if that is so - in their place where you will perform as they would like it (Hor Amoli, 1415, vol.12: 275).

There is no difference between the jurists that the interests can be changed, but some elders have been told that both the exchange and the exchange should be the same, not the interests, and perhaps this is the illusion that comes from this famous saying. The sale is for the transfer of lords, and it is very clear that this statement is not in the public interest, but has been made specifically for the exchange of will, such as rent, which is said to be for the benefit of the people, and is certainly intended to be exchanged, not exchanged.

The owner of the jewel writes: What emerges from the application of arguments and fatwas is that whatever is placed in front of the exchange can be changed; Whether a person is a general, an object, or a benefit, it is no different from a lease in this respect, but in terms of a privileged lease because the exchange in the sale is assigned to the object and in the lease to the benefit (Najafi, 1411, vol.8: 108).

\section{The topics of selling it have been learned}

Examining the opinions of jurists, we find that most jurists consider four issues for sale: a. The same B. The same general in a certain; J. The same general in the mind; D. Religion. Of course, some general jurists have even included the benefit and right in the definition of sale, and despite the above four issues, they consider "possession" to be the effect of the nature of sale, and most contemporary jurists consider this restriction to be the main effect of sale. And they do not consider the time of obtaining property in the sale of the same object with the sale of the same object or religion (Almasi and Azami Chahar Borj, 1390: 47).

\section{Types is important to sell and has a different Islamic jurisprudence Selling an exchange}

The concept of mere sale in the word means to convert, return an object and buy and sell and convert various currencies (Ragheb Isfahani, 1412: 482). In jurisprudential terms, mere is the buying and selling of gold and silver against each other: whether gold against gold, silver against silver, or one of the two against the other, whether Moscow or non-Moscow (Hosseini Ameli, 1419 AH, vol. 13: 538).

Naturally, selling something that is gold-plated or silver-plated will be considered as a mere sale (Sheikh Ansari, 1421: 56). But selling gold or silver to iron and copper coins and the like is not a mere sale (Qomi, 1423, vol. 4: 458).

\section{Marital sale}

From the point of view of some jurists, words play an essential role in contracts and their necessity. Therefore, if the customary contracts at the time of the Shari'a, such as sale or other contracts such as the exchange of exchanges are made without exchange of words, and for example the consent of the parties is declared only with receipts, these contracts cannot be the real example of the contract. And subject to the evidence of the obligation to be faithful to the contract. On the other hand, many jurists, especially contemporary jurists, consider the conclusion of a sale to be valid with any form of contract that is traditionally indicative of the intention of the parties, both verbal and non-verbal. Because what is necessary in the realization of the contract is that the mental validity of the parties is acceptable to the wise so that the legislator can sign it; And the rationalists consider any expression of carnal satisfaction to be acceptable, whether by word of mouth or by any other means. Accordingly, the sale can be divided into contractual (verbal) and non-contractual.

\section{The sale of pride}

Gharar (in the first and second conquests) is an Arabic word with various meanings, an excerpt of which is as follows: In some dictionaries of Persian, Gharar means death (Dehkhoda, 1330: 68), danger and deception. Eating is a deception in such a way that in transactions it causes harm 
to others or what causes the loss of someone or something (Moin, 1981: 139). Some jurists have stated that Gharar is a noun and is derived from Tahrir, and Tahrir means "to be exposed to destruction and annihilation" (Al-Shurtuti: 57). Gharar itself is an Arabic word that has several meanings; Such as "probability, probability of loss, close to death, acting on an action in which safety from harm is not present" (Khomeini 1363: 63). Mirfatah Maraghei has described Gharar in "titles" as follows: "Gharar" means negligence and cave; That is, carelessness and arrogance mean danger and change; That is, to make someone proud (Mirfatah Maraghei, 1297). What is clear is that Mirfatah considers arrogance to mean a danger.

\section{Good to good sale}

In terms of vocabulary, despite the similarity, there is no complete harmony in the concept of Kali to Kali.

The dictionary says in the article "Kola" that Kola Al-Din, Takhr and Al-Kali Al-Nisa '. And in the general article, it is explained that you should buy and sell the religion that you owe to another person with the religion that he is in charge of.

Al-Bahrain Assembly in its general article, considering the entry of the prohibition of such a sale, said that the meaning of that sale is the sale of the loan and the sale of the mafia has a deadline, for example, and explained that this is where food is sold through Salam and money. It is paid, but when the time comes to deliver the food, the seller says: There is no food, but he asks the buyer to sell it to him for a while. Sahib Majma 'al-Bahrain has said that this is a credit that has been returned to another credit but if it had been received and then sold, it would not have been realized in Kali (Tarihi, 1396: 57).

Finally, Ibn Athir is quoted as saying in the Bahrain Assembly, but in the second sale, another deadline is added, in addition to increasing the price.

From the words of the scholars, it is clear that there is a religion in Kali to Kali that is delayed, not that the religion itself originates from the sale itself. In the case where the seller re-buys the food through the predecessor, the seller is still responsible for it in the form of religion, and as a result of the sale of another person's religion, it exists at the time of the contract and does not result from the contract. In addition, in the religion they are in, they are not subject to money, because the appearance of the scholars is that in religion it is delayed.

\section{Trading from one to another}

In the sale of the transaction to the payee, both the price and the price are in full, and for the delivery of the two, a date is set and nothing is exchanged at the time of concluding the contract, such as selling ten tons of wheat to ten million rials, so that wheat will be sold in three months. Surrender and the price will be paid in monthly installments or against the delivery of wheat. Here are some important points to keep in mind:

1- In jurisprudence, the consensus of the jurists is that the bill of exchange in the parliament is one of the correct conditions for the sale of the predecessor. Because in a futures contract, the price is negotiable and the bill is not collected in the contract assembly, the futures contract is similar to the Salafi sale, where the price bill in the contract is not concluded. Therefore, this contract is in trouble in this regard. However, in jurisprudential texts, in order to argue the need for a bill of exchange in the contract assembly, only fame or consensus has been documented and the Qur'an and narration tradition have not been cited. Perhaps it can be said that since many jurists have cited the narration of the prohibition of religion against religion or have given other possibilities, therefore, assuming that there is a consensus on the issue, this consensus is probable and not a proof. In addition, according to some jurists, consensus is problematic.

2- In the sale of the transaction to the payee, the price and the value of both are general and, for the delivery of the two, a time limit is set and nothing is exchanged at the time of concluding the contract: such as selling ten tons of wheat to ten million rials, as wheat It will be delivered in three months and the price will be paid for the delivery of wheat.

Many jurists, considering that this contract is the same as the sale of Kali to Kali, consider it forbidden and invalid. Therefore, the jurisprudential opinion in the future contract, because both 
the price and the price are both valid, is one of the examples of sale from one to another, and according to the above jurisprudential opinion, this contract is void.

The sale of the transaction can be divided into two types:

1- A case in which the price or the price or both are at the time of performing the contract of religion, which is interpreted as the sale of religion to religion or Kali to Kali, and it is definitely invalid.

2- A case in which the price or the price or both are not at the time of performing the religion contract, but are done by performing the religion contract. According to some jurists, there is no reason to invalidate this type of contract.

\section{Sale of religion}

Religion is literally a loan with a certain deadline (Ibn Manzur, 1410: 459), but there are different terms in terms of terminology. The term religion in Shiite jurisprudence is not scattered from different points of view; It is as if some have merely considered the lexical argument sufficient, and have merely expressed the literal meaning of religion, and others have turned to the definition of sale. Some have considered religion to be a fixed general property in the liability of a person for the benefit of another for some reason (Tusi, 1408: 125).

Regarding the jurisprudential views on the sale of religion, several issues can be mentioned: 1. The sale of religion to religion is absolutely void. Sheikh Tusi in Al-Khalaf attributed this promise to Shafi'i and did not mention any reason for it. 2 . The sale of religion is valid, but the sale of religion is void. The first martyr in Al-Drous believes that Ibn Idris also believes that it is not permissible to sell the religion. Sahib Muftah al-Karama has quoted this view from a group such as Mohaghegh in Sharia, Allameh in Tahrir and Shahid in Lessons.

\section{Continuous sale}

Continuation of the word means extravagance in the sense that the seller wants to increase the price and the buyer wants to reduce it. Another name for it is fascination because each seller and buyer attracts their own benefit. (Tarihi, 1413, Vol. 1: 56).

"Equal sale" is a bargaining agreement in which the parties are free to negotiate and bargain to determine the price of the goods. The seller tries to make as much profit as possible, while the buyer tries to reduce the price of the product in any way possible. In such a contract, the seller has no obligation to disclose the initial price of the goods to the buyer. Consensus in Imami jurisprudence is not obligatory for the seller to inform the head of the treasury, but he is free to sell the goods several times what he has given or less than that (Allama Hali, 1414: 215). In Islamic jurisprudence, this type of sale has a special advantage over other transactions. Because it only follows the general rules related to sale and there is no specific ruling that makes the seller obligated to comply with them (Bagheri, 2005: 242).

\section{Sale of concessions}

The sources of the source are the source of the "thirst". In Al-Qamus al-Fiqhi, it is stated as follows: Ateha al-Shi'i: Na'lah al-Ihyah So concessions mean giving something to someone. The sale of concessions is also called the sale of concessions. It means taking and taking (Azarnoosh, 1992: 445). Therefore, in the sale of concessions, one party grants the contract and the other party receives the contract. Some have also called the sale of concessions the sale of exchanges or practical exchanges.

Although the study of the works of jurists in the definition of default sale shows that default sale is a practical and transactional writing resulting from the consent of the donors and is free from the form of writing the demand and acceptance with words, so the jurists including Mohaghegh Thani, Shahid Thani and Tabatabai Definitions have been defined as: "The sale of defaults is that each of the dealers gives something in return for what he receives from another" (Mohaghegh Thani: 215). But this meaning of default sale is ambiguous and its nature should be further analyzed and Be analyzed. Also, the initial idea from the point of view of the jurists is that all of 
them accept that the sale of concessions has no religious and legal truth and its meaning is the same as the literal meaning and customary situation (Ansari, $1420 \mathrm{AH}, \mathrm{J3}: 10$ ) and even when in doubt in quoting the literal and customary meaning. In the Shari'a sense, the principle (istihaab) is non-narration, but the accuracy of their words proves the opposite view, because they have given several theories in defining default sale and according to the Shari'a term, and have interpreted the nature of default sale in four meanings. Two of its interpretations are acceptable and two of its interpretations are unacceptable:

- The first interpretation is the sale of concessions, which is to say that each of the heretics will take possession of the other, without intending to possess it.

- The second interpretation is the sale of concessions, which is to say that each of the concessionaires who sell the concessions to another.

- The third interpretation is the sale of concessions so that the sale is not done with the intention of acquiring the said property, but each of the concessionaires gives something to another in order to eat something else, and the other party gives his property to him with the same intention.

- The fourth interpretation is the sale of concessions, which is the intention of absolute possession, without that intention being for sale.

Regarding the ruling on the sale of arrears, several theories should be mentioned: A. The opinion of Shiite jurists: Shiite jurists in this regard are divided into two main groups:

The first group are those who consider concessions as sale. Muhammad ibn Muhammad ibn Nu'man, known as Sheikh Mufid, Ayatollah Khoei, Faiz Kashani, Sheikh Ansari and Mousavi Khomeini, belong to this group.

The second group believes that concessions are not for sale and do not express property. Many early Shiite jurists, such as Tusi, Ibn Idris, Ja'far ibn Hassan Hali, Jamal al-Din Hali, Sahib alLuma, and some later jurists, such as Sahib al-Jawahir, believe in this ruling. (Ziaee, 2002: 170169).

B- The opinion of Sunni jurists: In Sunni jurisprudence, there are three opinions in this regard:

2- It is not permissible to sell concessions. The apparent jurists and many Shafi'i jurists, especially their predecessors, believe in this opinion.

2- If the sale of concessions is common among the people, it will be valid and concluded, otherwise it is not permissible and will not be concluded. Hanafis and Hanbalis believe so.

3- If the concessions clearly indicate the consent of the parties, the sale will be concluded, whether it is common among the people or not. This decision is in accordance with the Maliki religion and the principle of the Ahmad ibn Hanbal religion.

\section{Extinct sale}

Some jurists have mentioned the necessity of the sale at the time of the contract and some have not mentioned the existence of the sale under the conditions of the validity of the sale, but have stated that the sale of the deceased (absence of the sale at the time of the contract) is void. They have not specified the sale of the deceased, but they have considered the reason for the prohibition of the sale of some objects as the absence of the seller. For example, it is stated in "Sharh Lameh": "The permission to sell the fruit before the reappearance and the resurrection to the existence and the end of the time of the completion of Okam ..." (Shahid Aval, 1406: 95).

It is stated in the "titles": My explanation is that this condition (the rule of arrogance) is the condition of the knowledge of the existence of the substitute and the trustworthy (Maraghi: 134). And in Ayyad al-Ayyam, regarding the lack of trust in the realization of the existence of the preacher, we read as one of the cases and examples of arrogance: Exposure to Talaf (Fazel Naraghi, 1398: 158).

The risk is also realized on the basis of uncertainty about the realization of the existence of the transaction; In this case, one of the parties to the transaction is not sure of the realization and existence of the transaction, so in this case, the transaction is considered to be at risk of loss.

\section{Safe sale}

In the definition of Salafi sale, it should be said that a sale that most people do not conclude and usually does not take place with the wise, so that if such a transaction is issued by a person, it is understood that it was contrary to the method of the wise and this It is a transaction that has the 
authority and capability to be issued by an idiot, not a wise person (Hosseini Maraghi, 2009, vol. 2: 244).

Some jurists, without entering into conceptual analysis, refer to it as Salafi and sometimes analyze the reason for its inaccuracy; For example, the first martyr in Lameh, in the chapter on the rules of sale and the subject of criticism and credit, considers the high and low price of the real price if the customer is aware of the price of the seller, without any problems. Lead to sefe" (Shahid Aval, $1420,121)$. Shahid Thani, in describing the same subject, without entering into the analysis of Sefeh, states: "Sefeh rises to this excess and correct the excess of the price for the correct purpose, whether this excess is a small defect or another purpose is in front of it; Like patience to the present religion and the like" (Shahid Thani, 1410, vol. 3: 521). Although he did not enter into a conceptual analysis, he did; However, by stating the reason for removing the sofa, it can be understood that the meaning of the sofa is the lack of a wise and prudent purpose, not the lack of a lot of price alone.

Accordingly, according to the definitions made and the examples given by the jurists in their books, Salafi transactions in the general sense include a transaction that is so irrational that it is not expected by such wise people; Apart from whether the trader is an idiot or a wise man and whether other elements of the transaction are valid or not. Also, the Sufi transaction, in its specific meaning, is an irrational transaction that is made by a wise person and other elements of the validity of the transaction are also available (Hekmatnia and Zamani, 2013: 11).

However, the first martyr and others have raised the issue of negligence in the sale contract; However, such a transaction is not subject to the contract of sale and can be imagined in other exchange and non-exchange contracts; Because the criterion for the validity of the contract is that the contract is concluded in a way that is not common and acceptable to the people, and the fulfillment of these conditions is possible for other contracts, and even this criterion can be applied in terms and conditions. In short, in determining the cases of contracts, the criterion for validity in most transactions is that the transaction is based on the dominant method of the people and the habit of most intellectuals, and contracts that are not like this are among the contracts that are not common among people., Nature and Situation are placed under the title of the actions of the idiots, and this causes the transaction to be strained in any contract of contracts (and terms and conditions) and in any Babi (Hosseini Maraghi, 2009, vol. 2: 247 -248).

Some jurists, such as Sahib Jawaher, believe that the axis of many pillars and conditions of correctness or invalidity of transactions is the firmness or rationality of the transaction (Najafi, 1404, vol. 27: 302). Some recent jurists also believe that following the owner of the jewel:

We should not abandon the courts for the sake of similarities, but we should interpret the similarities through the courts, and one of the courts is that the futures trade is void; Whether it is a sale or a marriage and the rule of sefa is not limited to this case; It is the same in Hebe and other chapters (Makarem Shirazi, 1424, vol. 1: 20).

\section{Pillars of sale from the perspective of various Islamic jurists}

\section{Demand and acceptance}

The phrase (demand and acceptance) is obligatory or both words, such as the seller saying: I sold this product to you for one hundred tomans and the buyer says: I accepted or I bought it at this price; Or the present, which replaces the word, as if the two parties to the contract (due to an excuse such as Lali) are not able to speak, and by referring to the substitute for the word, to write and possess. The requirement that the original destination of the contract is written by the seller, and the acceptance that the written consent form is required is made by the customer. Early jurists, in fulfilling the sale, considered verbal demand and acceptance as conditional (Mohaghegh Hali, 1409: 267).

From their point of view, the sale of concessions, that is, buying and selling without the use of words and only with the agreement of the heart, was not a sale, and the only effect that could be arranged on such a transaction was considered to be the abomination of possession. (Allama Hali, 1413: 405).

In the realization of the contract of sale, there is a difference of opinion only with the surrender of the seller with the intention of acquiring it in exchange for the known exchange and taking it 
with the intention of owning the exchange (which is interpreted as concessions). In contrast, the later jurists do not consider the word subject and consider the sale or other contracts to be achievable in any way that expresses the intention and will of the parties. From this point of view, what is important is to "write" the will of the seller and the customer to realize the sale. For this reason, if words are used, transactions must be in the past tense (not the past participle).

\section{Buyer and seller:}

The seller and the customer are also considered as other pillars of the sale, and since they seize their property and assets through the sale, both must be wise, mature and mature. With the accumulation of these three conditions in a person, he is qualified in the jurisprudential term as a perfectionist and legally qualified. For this reason, the small, insane, idiotic transaction is doomed to invalidity (Ratini, 1416: 35). The conditions mentioned below are general terms in exchange contracts. On other side of the contract (seller and customer), maturity, reason, intention, discretion, ownership and non-enclosure are required. Of course, the last two conditions are considered to be the conditions of influence and effect of the contract, not the conditions of its validity.

Having the intentions of the parties to the transaction is also a condition for the validity of the sale. Drunk, unconscious, anyone who is unaware or even drowsy, or jokingly utters words that indicate a sale, is invalid due to lack of intention. However, regarding the authority that is used in Islamic law against reluctance and coercion, it should be said that the condition is the necessity of sale, not the condition of its validity. Therefore, if the person compels and threatens the sale, its legal influence will be based on his satisfaction after the reluctance to decline. Hence, in Islamic law, such a sale is called "repeated sale" and is considered correct but ineffective. (Mohaghegh Hali, 1409:

268). In the absence of a condition of discretion, if he is satisfied with the contract after reluctance, the well-known opinion is the correctness of the sale. Fuzuli's sale is similar. What is meant by that is the sale of a person to sell something, without the owner of the object himself or with the permission of the owner. Such a sale contract is also valid. But the need to find it will depend on the owner's permission; If he rejects it, the sale will be void, and if he agrees, it will be valid and effective. (Sheikh Ansari, 1410: 101).

\section{Property sold}

Because the exchange of property against property takes place in the sale, the seller himself must meet certain conditions.

The first is to have a tax; That is, to have lawful interests that are considered rational; Therefore, anything that is not taxable according to Islamic law or custom does not have the authority to be substituted; Customs such as flies and mosquitoes and sharia such as wine and pigs. That is, from the point of view of the Shari'a, it should be recognized as a commodity. Therefore, a handful of soils that are not considered customary property, or alcoholic beverages that the Shari'a does not tax, cannot be traded. (Shahid Aval, 1411: 94).

The seller must be able to buy and sell. Therefore, the sale of something that is prohibited by law or sharia is void and has no legal influence. This condition is considered by some. What this means is that the exchange does not belong to another right, such as: the endowment property, the property of the child and the property of the vow, therefore, it cannot be sold, because it is not the property of divorce. (Shahid Aval, 1411: 95).

Of course, the generality of the condition (meaning the inaccuracy of the sale in what belongs to another's right) has been challenged, except in cases such as waqf property to which the attachment of another's right contradicts the sale. (Sheikh Ansari, 1410, Vol. 4: 31).

Finally, the seller must be able to deliver and the seller must be able to deliver it to the buyer or to the buyer.

This means that the buyer and the seller have the power to deliver it at the time of delivery; therefore, it would not be right to sell a runaway slave that the seller does not have the power to deliver. Being possessive; it means either the ability to have a substitute for being a property, which is synonymous with the first condition, ie having a tax, or the current property. As a result, permissible things such as large seas and streams, the use of which is permissible for the general 
public (commonalities), are not mutually beneficial; Therefore, it would not be right to sell seawater and the fish in it before acquiring it (Najafi: 343). Being objective is another condition. Objective means any money that has a foreign determinant; whether it is a partial or general and general, a whole is in Dhimma or a whole is in a certain (general sale) in front of the object, benefit and right. Benefiting from exchange is rent, not sale. Of course, this condition is valid only on the part of the seller. On the side of the price, the objectivity is not the condition, but the benefits, as well as (according to the group) the transferable rights and even (according to others) the non-transferable rights, but the negligible can also be the price. (Sheikh Ansari, 1410: 9-8).

\section{The price of the contract of sale}

If the transaction price is money, the amount and other conditions must be known at the time of the contract; In such a way that there is no ignorance or ambiguity in it. For example, if the seller says I sold the house for any price set by someone and the customer accepts it, the transaction is void due to unknown price. Whenever the price of a transaction is a commodity, all the conditions mentioned for the seller also apply to the price. The exchange (both the seller and the price) must be known in terms of quantity, sex and the factors affecting the price, and the ignorance of the exchange in any of the mentioned dimensions causes the non-conclusion of the sale (Najafi: 406405). Knowing the seller and the trustee is another condition for the validity of the sale, and ignorance of it causes the sale to become a case of arrogant and void transaction. Therefore, it does not matter whether the seller is unknown in terms of quantity or the type and type, or its description, if the buyer's knowledge is not complete, the sale is void.

\section{Characteristics of the sale contract from the perspective of Islamic jurists Ownership of sale}

Ownership of a contract of ownership means that at the end of the contract, the transaction is transferred from one person to another, that is, with the occurrence of the contract, the transfer of ownership is obtained and the property is transferred from one party to the carrier and the other party to the other, Enters and as soon as the buyer and seller agree on the exchange of goods, they are exchanged automatically; In this way, Mutman becomes the property of the buyer and the price becomes the property of the seller.

Therefore, the receipt and contract of the price and the principal do not interfere with the principle of ownership (GHabooli Derafshani, 2015: 91).

This description, in cases where the seller is "general in debt" or "certain in general", is faced with the problem that in these cases only the obligation arises for the seller to determine the seller and submit to the buyer, but at the time of the contract, the same There is no specific owner. To get rid of these problems, some have said: The whole, according to customary law, is money per existing limit that can be exchanged. (Tabatabai Yazdi: 35).

In such cases, one group considers "ability and talent" to be the subject of possession and others consider possession to be "judgmental or hypothetical." Perhaps it can be said that the contract of sale in all cases is the cause of possession; The contract creates the necessity of ownership, and the condition, which is the determination of the case, is obtained later, and the fulfillment of the condition does not require an additional or complementary cause. In fact, the proprietary contract with this analysis is a special face of the "covenant" contract, which is realized by determining the general instance by the obligor; and because in any case, the contract of sale is effective in possession, the general sale can be called "possession".

Although this analysis covers various instances of sale, especially in cases where the seller arises in the future and gradually, at the same time it seems that it interferes with the sale and ownership of the sale and destroys the boundary between the two, and thus the description. Ownership of the sale is limited to the sale of a specific object. Some scholars argue that the property transferred by the parties to the contract of sale is a credit that does not require the existence of a subject abroad, such as the nature and objections, and the exchange that strengthens the concept of sale between "two financial credits" for each other. It is a financial property that is reasonably considered to be a credit, and this financial exchange, which shifts the seller-buyer ratio to the seller and the price, should not be confused with the spatial transfer of objects. 
Spatial transfer, which is real, requires a specific subject; Unlike the transfer of property, which is a matter of credit. Trade is the cause of credit, not real. In this case, the general sale can also be considered as ownership.

\section{Exchanging the sale}

In exchange contracts, the two parties to the contract are usually at odds with each other, and each is thinking of their own profit and income, in which the two properties or obligations are exchanged, and the owner of each tries to oppose what is available. They bring wealth or commitment to excellence. And arrogance does not have a way in which this category of contracts is actually called exchange contracts. In other words, it refers to a contract in which the exchange of property is done by the parties, such as: sale and lease. Because it involves obligation and commitment from both parties (Jafari Langroudi, 2007: 173).

\section{The objectivity is the property}

Some have considered the word objectivity (ein) in the definition of sale to be what stands against profit and right. In their view, objectivity can be personal; it can be the general commonality, the generality in the definite, and the generality and debt (Rowhani, $1412 \mathrm{AH}$, vol. 15: 195). It seems that for this group of jurists, the objectivity is either present and noticeable in the external world or will be noticeable if it is realized in the world; therefore, the benefit that is lost in the external existence or the right that is merely valid and cannot be mentioned in the external world is not objectivity. Some commentators on Sheikh Ansari's Makaseb stated that the word objectivity is used in various meanings in the statements of jurists. Sometimes objectivity is used against the unknown; as it is used in the famous narration "until you know what is forbidden" and the purpose is to know the forbidden in such a way that there is no ignorance in. Or when the jurists say "sell something for a certain price", it is used in a non-passive sense; but in another usage, objectivity means the thing that is not obligatory; that is, it is used against what is obligatory. Such as when the jurists say, and among the conditions for allowing delay is that the things are quite similar, i.e. the totality is not in debt. But in other cases, objectivity is used for profit; it is similar to what they say, "in sale the property must be objective." What it means here is that the property is not a beneficiary and the use of the word "object" in the definition of sale means its final meaning, and therefore involves the personal object, the general in the outside world and the general in debt (Sheikh Ansari, 1418 AH, vol. 2: 5). In this definition, it seems that objectivity should be considered as the finance that can be mentioned in the external world or, if realized in the outside world, it can be mentioned.

There is no text in the sources of jurisprudence for the necessity of the objectivity of the property - which has been specified by many jurists - and no exact mention can be found in the works of the early jurists. Conversely, evidence can sometimes be found in the tradition that mention that the property may not be objective; as in a narration attributed to Imam Kazem, the interests and placement of a house whose owner is unknown are considered to be for sale instead of the same house (Sheikh Horr Ameli, 1403AH: 250).

\section{The necessity of the sale contract}

The principle in sale is necessity; i.e., the parties do not have the right to break the contract, except on conditions or by consent or by offering some options. In spite of the fact that stability and order in trade are not compatible with the need for the sale, the contract is not binding as long as the parties are present in the contract assembly, and the parties have the right to terminate the transaction. This right of termination is called the option of termination. In selling animals, where the object of sale is usually exposed to defects and complications and there is less possibility of being aware of those defects and complications during the contract, the customer has the right to terminate the contract within three days from the time of the contract, and this right is called the authority option for animals. There is a difference of opinion among jurists as to whether this option belongs to the customer or if the price of the transaction is an animal, the seller would have the right to terminate the transaction. The famous opinion of Imami jurists is to assign the authority option for animals to customers (Allameh Helli, 1984: 480). 


\section{Conclusion}

The contract of sale has a legal effect as soon as the will of the constituent parties, i.e. the seller and the customer, is realized, without ceasing the completeness of its effect on another matter. On the other hand, sale is a required contract and cannot be disrupted without a reason. The ownership of the sale is another aspect that distinguishes it from many other contracts, that is, after the sale is realized, the relationship of the seller's property with the property is terminated, and the customer becomes the owner; as the transformation to the same takes place in the price and the customer's relationship with it will be broken, and the seller owns it. The recent transformation is the result of another feature of the sale, namely its "exchangeability". Hence, the jurists have invalidated the harmful sale, in which at least one of the exchanges is unknown.

According to Imami jurists, sale has four terminological meanings: a) the transfer of the object from one person to another in exchange for a certain replacement by mutual consent; b) the demand and acceptance that imply transfer or a composed contract of demand and acceptance; c) transferring in a specific form; d) the will to own the property d) writing the acquisition of the same property (in exchange for property). This definition is the privileged and best in the viewpoint of the late Sheikh Ansari. It is worth noting that the title of sale, as it is applied to the seller's deed (i.e., the will to own in exchange for a known exchange), is also applied to the customer's deed (i.e. the will of possession of what the seller possesses). As the transaction is composed of the two acts of the seller and the buyer (i.e., the will to possession and transaction (trade)), it is also referred to as sale. The latter concept has been the subject of many Shari'a rulings, such as salvation, sanctity, correctness and corruption. The contract of sale, like other contracts, consists of two wills: a) the will to possess the goods in exchange for the known replacement, and b) the will to possess that replacement, which consists of the first, demand, and the second, acceptance.

Also, from the point of view of Islamic jurists, sale can be divided in various ways. Among the contracts, both definite and indefinite, the sale has the highest divisions, as in Islamic jurisprudence books more than 30 types are considered for it. Among the most important types of sale, bargaining, credit, Salaf, debt, and Ma'atat can be mentioned.

\section{Reference}

Allama Heli, Hassan Ibn Yusuf. (1413). Rules of Judgment, Vol. 1, No. 1, Qom: Islamic Publishing House.

Allame Heli, Hassan Ibn Yus. (1414). Tazkerat al-Faqha, Qom: Mursa al-Bayt (AS).

Ansari, Morteza. (1996). Al-Makasib, Qom: Islamic Thought Assembly.

Bagheri, Ahmad. (2005). the concept of sale in words and terms, Theology Quarterly, Third year, No. 7.

Ghabooli Darafshan, Seyed Mohammad Hadi. (2015). Analysis of the covenant or ownership of the general sale in Imami jurisprudence and subject law, Quarterly Journal of Jurisprudential and Principled Studies, First year, No. 1.

Hakim, Seyed Mohsen (Undated), Al-Arwa Al-Wathqi, Qom: Dar al-Tafsir Institute.

Hekmatnia, Mahmoud \& Zamani, Jafar. (2013). Legal status of private transactions in Imami jurisprudence and Iranian law / Quarterly Journal of Islamic Law, Tenth Year, No. 36.

Hor-Ameli, Mohammad Ibn Hassan. (1415). Shiite means, Beirut: Dar Al-Ahya Al-Tarath AlArabi.

Hosseini Maraghi, Mir Abdul Fattah. (2009). Fiqh titles. Qom: Islamic Publishing Institute.

Jafari Langroudi, Mohammad Jafar. (2007). Property Rights, Tehran: The Treasure of Knowledge.

Khoei, Abolghasem. (1422). Mesbah al-Faqah, Qom: Davari Publications.

Khomeini, Seyyed Ruhollah. (1363). Tahrir al-Wasila, Qom: Imam Khomeini Publishing House.

Khomeini, Seyyed Ruhollah. (2000). Kitab al-Bay'a, Tehran: Imam Khomeini Publishing House.

Makarem Shirazi, Nasser. (1424). Al-Qawaed Al-Fiqhi, Qom: Amir Al-Momenin School Publications. 
Mohaghegh Hali, Ja'far ibn al-Hasan. (1409). Sharia of Islam, Beirut, Dar Al-Sadr.

Mohaghegh Karki, Ali Ibn Hussein. (1408). Jama 'al-Muqassid fi al-Sharh al-Qawad Qom: AlBayt Publishing.

Najafi, Mohammad Hassan. (1989). Jawaher Al-Kalam, Tehran: Islamic Library.

Naraghi, Ahmad Ibn Mohammad Mehdi (2019), Shiite Documentary on the Rules of Sharia, Qom: Al-Bayt Foundation.

Qomi, Mirza Abolghasem. (1423). Rasa'il al-Mirza al-Qomi, Qom: Islamic Propaganda Office. Ragheb Isfahani, Hussein. (1412). Al-Mufradat Fi Gharib Al-Quran, Beirut: Dar al-Alam. Rouhani, Seyed Sadegh. (1412). Minhaj al-Fiqh, Qom: Anwar al-Huda.

Shahid Aval, Muhammad ibn Maki. (1406). Damascene shine, Qom: Islamic Publishing Office. Shahid Aval, Muhammad ibn Maki. (1420). Al-Droush Al-Shari'a Fi Al-Fiqh Al-Imamiya. Qom: Islamic Publishing Office.

Shahid Thani, Zayn al-Din ibn Ali. (1401). Gorgeous reluctance to explain the shining emblem, Qom: Referee Publishing.

Shahid Thani, Zayn al-Din ibn Ali. (1410). Masalak al-Afham, Qom: Islamic Education Center. Shahroudi, Seyed Mahmoud \& et al. Culture of Jurisprudence According to the Religion of the Ahl al-Bayt (Undated), Qom: The Encyclopedia of Islamic Jurisprudence on the Religion of the Ahl al-Bayt (as).

Sheikh Tusi, Mohammad Ibn Hassan. (2008). Al-Khalaf, Qom: Islamic Publishing House.

Sheikh Tusi, Muhammad ibn Hassan. (1408). Tahzib al-Ahkam, Tehran: Islamic Library.

Tabatabai Yazdi, Seyed Mohammad Kazem, (Undated), Al-Urwa Al-Wathqi, Qom: Islamic Publications Office affiliated with the Teachers' Association Seminary.

Tabatabai, Ali ibn Muhammad. (1419). Riyadh Al-Masa'il, Qom: Al-Bayt Institute.

Tarihi, Fakhreddin. (1413). Bahrain Assembly, Tehran: out of place.

Ziaei, Mohammad Adel. (2002). the sale of concessions and the effect of custom on its correction, Quarterly Journal of Articles and Reviews, No. 